\title{
Evaluasi Kebutuhan Air Persemaian di Kawasan Karst Nggorang Manggarai Barat, Labuan Bajo, Nusa Tenggara Timur
}

\author{
Erik Febriarta ${ }^{1}$, Aditya Pandu Wicaksono ${ }^{2}$, Dobrak Tirani Tegak Nurani ${ }^{3}$, dan Ajeng \\ Larasati ${ }^{4}$
}

\author{
${ }^{1}$ Magister Pengelolaan Pesisir dan Daerah Aliran Sungai, Fakultas Geografi, Universitas Gadjah Mada, Daerah \\ Istimewa Yogyakarta; e-mail: e.febriarta@gmail.com \\ ${ }^{2}$ Teknik Lingkungan, Fakultas Teknologi Mineral, Universitas Pembangunan Nasional "Veteran" Yogyakarta, \\ Daerah Istimewa Yogyakarta \\ ${ }^{3}$ Program Studi Geofisika, Fakultas Matematika Dan Ilmu Pengetahuan Alam, Universitas Gadjah Mada, Daerah \\ Istimewa Yogyakarta \\ ${ }^{4}$ Palawa Karya, www.palawakarya.co.id, Daerah Istimewa Yogyakarta
}

\begin{abstract}
ABSTRAK
Rehabilitasi lahan dan reklamasi hutan merupakan dua contoh upaya pemenuhan kebutuhan akan kayu nasional. Program ini melibatkan proses regenerasi tanaman yang diawali dengan pembibitan tanaman hutan, misalnya dengan metode persemaian modern yang dapat mempercepat waktu kesiapan bibit. Persemaian modern merupakan pengembangan dari program kebun bibit yang telah dilaksanakan oleh Kementrian Lingkungan Hidup dan Kehutanan (KLHK) Republik Indonesia. Sejalan dengan penetapan tujuan wisata super prioritas di Danau Toba di Sumatera Utara, Borobudur di Jawa Tengah, Mandalika di Nusa Tenggara Barat, Likupang di Sulawesi Utara, dan Labuan Bajo di Nusa Tenggara Timur, perencanaan persemaian modern difokuskan di Satar Kodi, Kelurahan Nggorang, Komodo, Manggarai Barat. Dalam hal ini, ketersediaan air menjadi faktor yang penting karena diperlukan sepanjang tahun, terlebih saat puncak musim kemarau. Keterdapatan air tanah sebagai sumber air kegiatan rangkaian persemaian dapat diketahui dengan pendekatan geofisika dan analisis data resistivitas. Metode pendugaan air tanah Vertical Electrical Sounding (VES), yakni injeksi arus listrik ke dalam bumi melalui dua elektroda potensial, digunakan untuk menghasilkan resistivitas. Melalui analisis matching curve, nilai log resistivitas dikorelasikan dengan nilai log batuan dan menghasilkan root mean square (RMS) sebesar 8,4\%. Hasil analisis menunjukkan bahwa penyusun batuan terdiri atas batugamping dari Formasi Batugamping Berlapis (Tml) dan batulempung dengan sisipan tufan. Air tanah ditemukan di akuifer batugamping tufan yang, berdasarkan susunan batuannya, memiliki dua lapisan akuifer, yakni lapisan atas (kedalaman 7,5-24,04 m, potensi debit air tanah 5,68 liter/debit) dan lapisan bawah (kedalaman 46,24-106,68 m, debit 74,63 liter/detik). Lapisan bawah memiliki akuifer tebal $(60,24 \mathrm{~m})$ dan kedalaman potensial untuk sumur bor. Potensi ketersediaan air lebih dari cukup untuk memenuhi kebutuhan air persemaian modern.
\end{abstract}

Kata kunci: Resistivitas, Batu gamping, Air tanah, Persemaian, Debit air

\begin{abstract}
Land rehabilitation and forest reclamation are among the strategies adopted to meet national demand for timber, and, for this purpose, forest plant nurseries should be prepared to regenerate new plants. Modern nursery, believed to shorten the time needed to produce transplants, is part of the nursery program introduced by the Ministry of Environment and Forestry (KLHK) of the Republic of Indonesia. In line with the determination of Lake Toba in Sumatera Utara Province, Borobudur in Jawa Tengah, Mandalika in Nusa Tenggara Barat, Likupang in Sulawesi Utara, and Labuan Bajo in Nusa Tenggara Timur as superpriority tourist destinations, the modern nursery is currently prepared solely for Satar Kodi, Nggorang Subdistrict, Komodo, Manggarai Barat. Because it requires continuous supplies of water throughout the year, notably at the peak of the dry season, this research set out to determine groundwater availability using a geophysical approach and resistivity data analysis. Vertical Electrical Sounding (VES), which injects an electric current into the ground through two potential electrodes, yielded resistivity values. In the matching curve analysis, the log values of both resistivity and rock constituents were correlated, resulting in a root mean square (RMS) of $8.4 \%$. The analysis revealed that the rock constituents were the limestone of the Bedded Limestone Formation (Tml) and claystone with intercalations of tuff. Groundwater was detected in tuffaceous limestone aquifer that, based on the rock arrangement, had two aquifer layers: the upper layer (depth= 7.5-24.04 m, discharge potential $=5.68 \mathrm{l} / \mathrm{s})$ and the lower layer $(\mathrm{depth}=46.24-106.68 \mathrm{~m}$, discharge potential $=74.63 \mathrm{l} / \mathrm{s})$. The lower layer had a thick aquifer $(60,24 \mathrm{~m})$ and potential depth for boreholes. Overall, groundwater availability is more than sufficient to meet the water needs of the modern nursery.
\end{abstract}

Keywords: Resistivity, Limestone, Groundwater, Nursery, Water Discharge

Citation: Febriarta, E., Wicaksono, A.P., Nurani, D.T.T., dan Larasati, A. (2020). Evaluasi Kebutuhan Air Persemaian di Kawasan Karst Nggorang, Labuan Bajo, Nusa Tenggara Timur. Jurnal Ilmu Lingkungan, 18(3), 572-581, doi:10.14710/jil.18.3.572-581 


\section{Latar Belakang}

Kementrian Lingkungan Hidup dan Kehutanan (KLHK) Republik Indonesia mempunyai program nasional dalam rangka memenuhi kebutuhan akan kayu dalam negeri dengan 1.000 kebun bibit dan 51 persemaian modern di seluruh Indonesia. Fungsi utama dari kebun bibit dan persemaian modern merupakan salah satu upaya dalam percepatan kesiapan bibit tanaman dalam rangka regenerasi tanaman baru untuk rehabilitas dan reklamasi hutan. Rencana Lokasi persemaian modern berada di Kawasan Hutan Produksi Nggorang Bowosie. Lokasi untuk persemaian modern berada secara administrasi berada di Satar kodi, Kelurahan Nggorang, Kecamatan Komodo, Kabupaten Manggarai Barat, Nusa Tenggara Timur atau berjarak $\pm 15 \mathrm{~km}$ arah tenggara dari Kota Labuhan Bajo. Perencanaan persemaian modern memiliki syarat kondisi kemiringan lereng lahan datar sampai dengan landai, memiliki luas 30 - 50 hektar untuk sarana prasarana persemaian, sumber benih, arboretum, dan keperluan lain untuk estetika, akses jalan menuju lokasi persemaian relatif mudah, tersedia sumber air dan/atau air tanah dalam jumlah memadai, potensi konflik minimal dan dekat/ tersedia jaringan listrik dan telekomunikasi (Hadi, 2020). Dalam perencanaan persemaian bibit tanaman hingga siap tanam, faktor utama adalah ketersediaan air terkait lokasi persemaian (Kurniaty dan Danu, 2012).

Sumber daya air merupakan kebutuhan dasar bagi manusia dan makhluk hidup disekitarnya (Kurniaty dan Danu, 2012; Febriarta dkk, 2018). Ketersediaan sumber air di lokasi persemaian dan perbenihan tanaman hutan harus mencukupi selama satu musim, terlebih musim kemarau (Pramono dkk, 2016; Permen LHK, 2020). Ketersediaan air dalam masa persemaian bibit tanaman mengambil faktor penting selain sumber nutrisi dan mempertahankan kelembaban di sekitar persemaian (Pramono dkk, 2016; Balasubramanya and Stifel, 2020; Valliano et al, 2020). Sehingga dalam perencanaan persemaian, jika berada di daerah yang terbatas akan sumber daya air nya (secara geologi maupun hidrologi atau curah hujan yang kecil) perlu dilakukan upaya keteknikan penyediaan air dari sumber air lain atau mendatangkan air dari sumber lain (Traitler dkk, 2018; Febriarta dan Oktama, 2020).

Pemetaan sumberdaya air merupakan Langkah strategis dalam perencanaan kebutuhan air pada sktor tertentu (Fetter, 2004; BSN, 2005; Abrishambaf et al, 2020; Febriarta dan Purnama, 2020; Febriarta dkk, 2020). Keterdapatan air tanah, dipengaruhi oleh sifat batuan pembawa air tanah yang ditunjukkan dengan sifat fisik antar butir batuan (Todd and Mays, 2005; Singhal and Gupta, 2010; Febriarta dan Larasati, 2020). Dari sifat media antar butir tersebut, potensi air tanah semakin memiliki rongga antar butir yang besar dengan material lepas-lepas, sedangkan media akuifer berupa batuan berpori kecil atau celah atau rekah memiliki potensi relatif kecil maupun setempat (bersifat lokal) (Fetter, 2004; Febriarta dkk, 2019).
Secara formasi geologi, lokasi persemaian berada di wilayah batugamping yang berada pada Formasi Batugamping Berlapis (Tml). Formasi Batugamping Berlapis (Tml) tersebut didominasi oleh batugamping. Kawasan tersebut masuk berada di kawasan bentang alam karst (KBAK) Nggorang Mangarai Barat (Gambar 1). Defini karst adalah bentang alam yang terbentuk akibat pelarutan air pada batugamping dan/ atau dolomit, sedangkan kawasan bentang alam karst adalah karst yang menunjukkan eksokarst dan endokarst tertentu (Singhal dan Gupta, 2010; Permen ESDM, 2012). Kawasan hidrogeologi karst dicirkan dengan akuifer dengan aliran celah, rekah, saluran maupan pelarutan (Singhal dan Gupta, 2010). Kawasan karst dengan batuan penyusun batugamping memiliki korelasi dengan keterusan air tanah kecil hingga sedang dan keterdapatan air tanah terbatas (Milsom. 2003; Fetter, 2004; ESDM, 1995a; Singhal and Gupta, 2010).

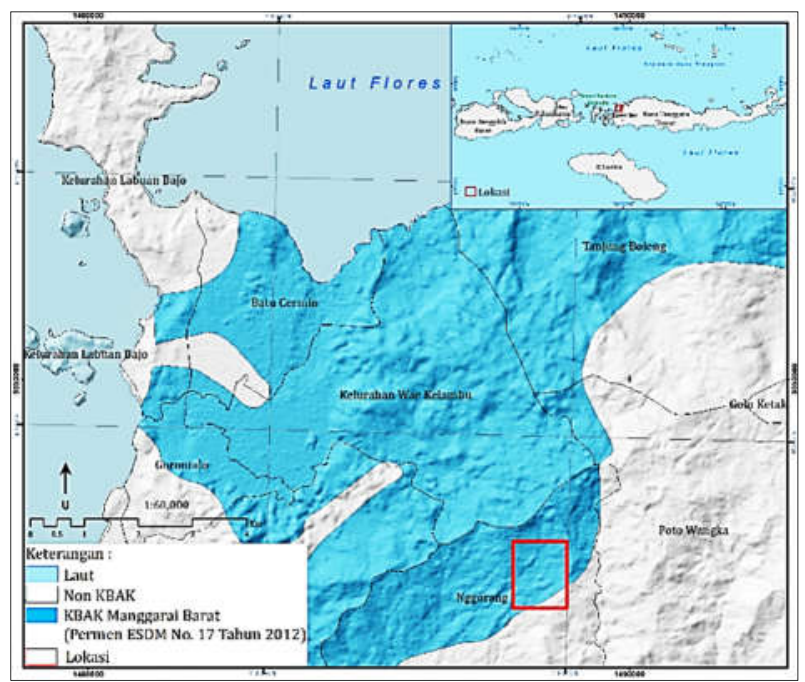

Gambar 1. Lokasi Kajian Berada di Kawasan Bentang Alam Karst (KBAK) Nggorang Manggari Barat

(Permen ESDM, 2012)

Kebutuhan air terhadap suatu kebutuhan tertentu dapat diperoleh dari ketersediaan air (cadangan air tanah) terhadap kebutuhan air, dalam hal ini persemaian tanaman (Traitler dkk, 2018; Febriarta dkk, 2020.) Ketersediaan air tanah dapat diketahui dengan pendekatan geofisika terhadap keterdapatan air tanah (Milsom, 2003; Fetter, 2004). Metode Vertical Electrical Sounding (VES) dapat memberikan informasi tentang penysusun lapisan batuan dan dapat diidentifikasikan keterdapatan air tanah dari nilai log resistivitas (Telford et al, 2004; Lowrie and William, 2007; BSN, 2012). Untuk mengetahui nilai tanahan jenis, pengukuran dilakukan dengan injeksi dua elektroda kedalam bumi dengan sususan konfigurasi schumberger. Konfigurasi tersebut memberikan keuntungan distribusi nilai yang diukur dapat merambat dengan kedalaman maksimal kedalam bumi (Telford et al, 2004; Lowrie and William, 2007; BSN, 2012). Arus listrik merupakan media sifat listrik untuk mengukur nilai resistivitas (tahanan jenis). Resistivitas suatu 
material (perlapisan batuan) akan menunjukkan tingkat hambatannya terhadap aur listrik. Nilai resistivitas yang semakin besar, maka sulit untuk menghantarkan listrik dan nilai sebaliknya, jika nilai resitivitas kecil maka menjadi penghatar listrik yang baik. Perbedaan nilai dari resitivitas tersebut digunkan sebagai penentuan material penyusun batuan (Febriarta dkk, 2019; Maino et al, 2019).

Berdasarkan lokasi perencanaan persemaian tanaman bibit hutan berada di kawasan karst dengan ciri-ciri kondis hidrologi (air tanah) terbatas hingga langka pada batugamping yang secara geologi termasuk produktifitas kecil. Untuk mengetahui pemenuhan air untuk persiapan persemaian modern dapat diketahui dengan evaluasi dari nilai neraca ketersediaan terhadap kebutuhan bibit tanaman hutan. Sehingga untuk mengetahui evaluasi tersebut, maka tujuan dari kajian adalah mengetahui potensi keterdapatan air tanah, yang terdiri atas kedalaman lapisan air tanah, penyusun litologi akuifer dan potensi debit air, serta neraca kebutuhan air untuk persemaian di kawasan karst (batugamping) di Nggorang Manggarai Barat.

\section{Kondisi Geologi dan Hidrogeologi}

Lokasi perencanaan persemaian modern di Nggorang secara geologi regional berada pada Formasi Batugamping Berlapis (Tml) terbentuk pada masa miosen tengah (tersier). Berdasarkan statigrafi pengendapannya, merupakan batuan sedimen. Formasi Batugampung Berlapis (Tml) tersusun atas batuan batugamping berlapis berwarna kelabu, pejal, mengandung sisipan-sisipan batugamping tufaan, batupasir kwarsa, tufa dan konglomerat (ESDM, 1995a; ESDM, 1995b). Konglomerat terdapat di bagian foraminifera, koral dan moluska. Fosil yang dikenali adalah Lepidocyclina ephipiodes, Lepidocyclina omphalus (Tan), Flosculinella bontangenis (Rutten), Operculina sp., Amphistegina sp., dan Flosculinella sp, yang menunjukkan umur Miosin. Satuan ini ditutupi selaras oleh batugamping tufaan (Tmpl) dan dialasi tidak selaras oleh batuan gunungapi (Tlmv), mendatar beralih menjadi piroklastik kasar (Tmv) dan piroklastik halus (Tmdt) (Ratman dan Yasin, 1978). Berdasarkan keterdapatan material urat-urat kwarsa dengan galena setempatsetempat terdapat di dalam satuan fromasi gunungapi tidak selaras. Lokasi tersebut, terdapat geostruktur berupa patahan dengan arah barat daya-barat laut dengan bagian terangkat bagian utara, dan bagian yang turun bagian selatan (Gambar 2). Struktur yang berkembang pada daerah ini adalah berupa sesar normal dan kelurusan yang umumnya berarah timurlaut - baratdaya. Struktur tersebut umumnya terdapat pada batuan - batuan berumur miosen tengah dan miosen-pliosen.

Berdasarkan formasi penyusun batuan, keterdapatan air tanah berada pada batuan batugamping dan batupasir gampingan, serta rombakan batuan gunungapi gampingan. Secara umum keterdapatan air tanah berada pada batu gamping. Karakteritik akuifer pada formasi tersebut 574 merupakan akuifer dengan media penyimpanan air tanah celahan, rekahan dan saluran pelarutan, dengan produktivitas sedang (ESDM, 1995a). Di kawasan karst Nggorang Manggarai barat terdapat patahan (sesar) menunjukkan kondisi batuan yang kompak, (batugamping) berdasarkan sifat aliran air tanah, dimungkinkan aliran air yang berada di celah atau jalur rekahan antar sesar tersebut, sehingga memiliki potensi air sedang hingga tinggi (Ratman dan Yasin, 1978; ESDM, 1995b).

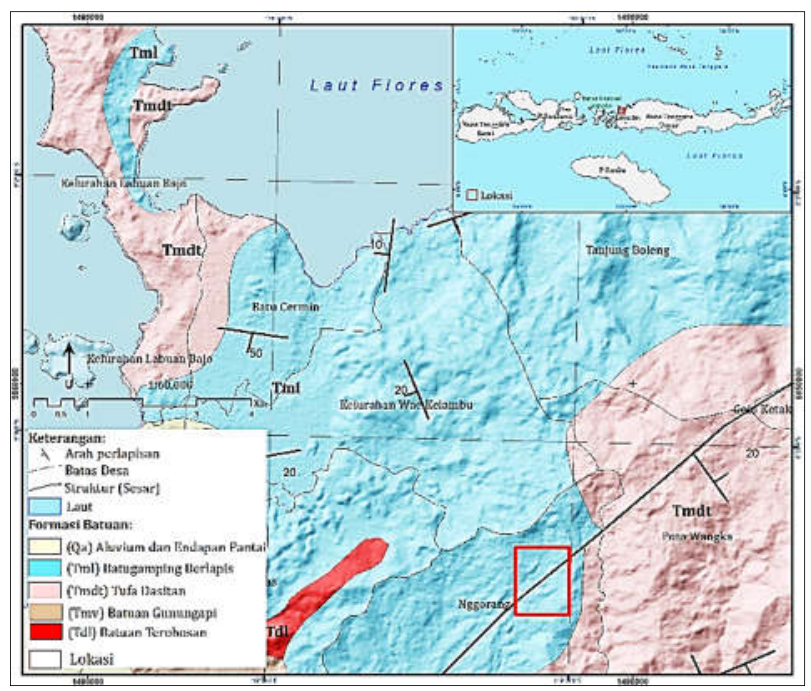

Gambar 2. Geologi Regional

(Formasi Batugamping Berlapis)

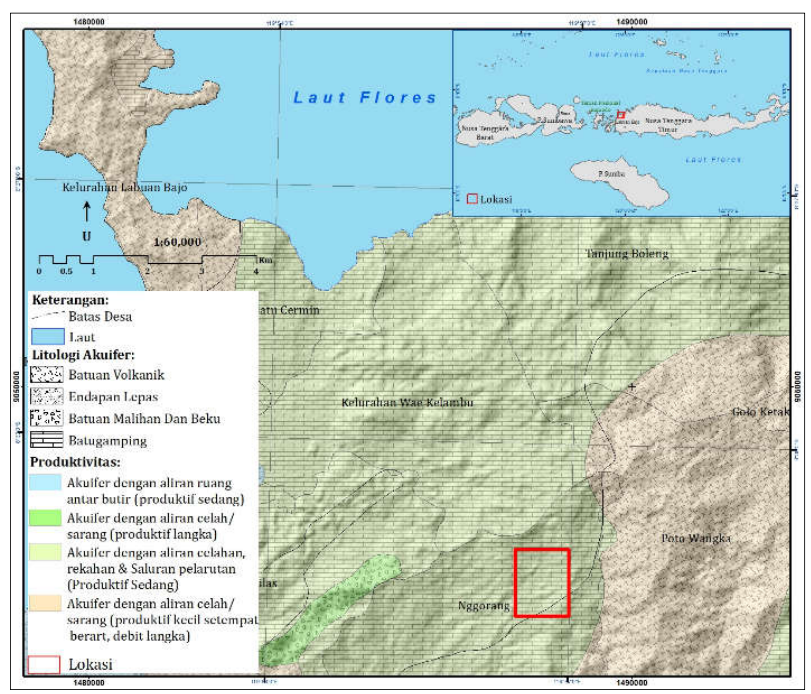

Gambar 3. Kondisi Hidrogeologi Nggorang

(Produktifitas Air Tanah Sedang)

Definisi akuifer adalah air yang berada di dalam permukaan bumi yang dibatasi oleh lapisan kedap air. Sedangkan akuifer karst secara umum berada di aliran celah, rekah maupun aliran pelrutan. Perkembangan dari akuifer karst di Nggorang Manggrai Barat disekitar lokasi persemaian modern (Gambar 2) berada akuifer dengan litologi batugamping dengan sifat aliran antar celah hingga pelarutan dengan potensi debit air tanah berkisar 210 liter/detik (ESDM, 1995a; ESDM, 1995b). Potensi air dengan produktifitas yang sedang hingga tinggi 
tersbut, dipengaruhi oleh geometri cekungan air tanah yang luas, yaitu masuk di daerah cekungan air tanah (CAT) Labuan Bajo, dimana daerahnya menyebar dari perbukitan batugamping bagian selatan menuju ke bagian utara atau bagian pantai dan pusat kota Labuan Bajo (ESDM, 2018).

\section{Metodologi Penelitian}

\subsection{Analisis Keterdapatan Air Tanah dari Data Resistivitas (Geolistrik)}

Kajian evaluasi kebutuhan air persemaian di kawasan karst Nggorang dilakukan dalam beberapa tahap, yaitu pengukuran nilai tahanan jenis (resistivitas), analisis matching curve untuk mendapatkan penyusun lapisan batuan, kemudian analisis sifat hidrogeologi untuk lapisan keterdapatan air tanah, dan perhitungan neraca air antara ketersediaan air tanah terhadap penggunaan air untuk persemaian modern.

Pendugaan keterdapatan air tanah dengan geolistrik menggunakan bentangan maksiman $(\mathrm{AB} / 2)$ adalah $250 \mathrm{~m}$. Konfigurasi arus pontensial menggunakan schumberger yang menghasilkan nilai daya voltase (V) dan arus yang diterima (I). Konfigurasi schlumberger (Gambar 4), diukur dengan memindahkan elektroda arus secara logarritmik dan elektroda potensial tetap (Telford et al, 2004; Todd and Mays, 2005; BSN, 2012). Kelebihan dari konfigurasi schumberger untuk penyelidikan perlapisan batuan adalah memiliki penetrasi kedalaman paling baik, dengan persamaan nilai resistivitas semu (BSN, 2012; Uhlemann et al, 2017), sebagai berikut:

$$
\rho_{a}=k \frac{v}{t}
$$

dimana :

$\rho$ : nilai resistivitas hasil lapangan

$\mathrm{k} \quad$ : nilai faktor geometri, diperoleh dari rumus persamaan (2)

$\mathrm{v} \quad$ : nilai beda potensial (voltase)

I : nilai arus listrik

Nilai (k) faktor geometri menggunakan rumus pendekan pendekatan (Todd and Mays,2005; BSN, 2012; Ungureanu et al, 2017), sebagai berikut:

$$
k=\pi \frac{s^{2}-(2 b)^{2}}{2(2 b)}
$$

dimana:

$\mathrm{k} \quad$ : nilai faktor geometri

$\pi \quad: 3,14$ atau $22 / 7$

s $\quad$ : jarak elektroda areus ke pusat (Gambar 4)

2b : jarak elektroda ke potensial MN (Gambar 4)

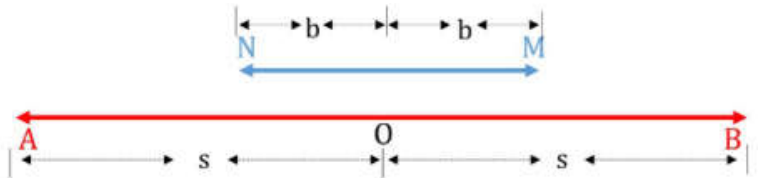

Gambar 4. Rangkaian Elektroda Konfigurasi Schumberger (Lowrie and William, 2007; BSN, 2012)
Hasil dari perhitungan pa (nilai resistivitas lapangan) dari rumus 1 dan rumus 2, tahap selanjutnya adalah pengolahan nilai dengan pendekatan matching curve dari dari data resitivitas (tahanan jenis) semu menjadi hasil berupa log resistivitas sebenarnya (Lowrie and William, 2007; Ungureanu dkk, 2017). Penyesuaian hasil log resitivitas tersebut dikorelasikan dengan material batuan (litologi) mengacu nilai resistivitas terhadap batuan pada Tabel 1 .

Tabel 1. Nilai Resistivitas (Ohm m) Pada Perlapisan Batuan

\begin{tabular}{lc}
\hline \hline \multicolumn{1}{c}{ Batuan (litologi) } & Resistivitas (ohm m) \\
\hline Batuanbeku dan metamorf & $1.000->100.000$ \\
Batubeku, kerikil dan pasir & $1.000-10.000$ \\
Batu konglomerat & $1.000-10.000$ \\
Batupasir & $100-1.000$ \\
Lempung & $5-100$ \\
Lumpur & $5-50$ \\
Air tawar & $5-500$ \\
\hline Sumber: Telford dkk, 2004; Lowrie and William, 2007
\end{tabular}

\subsection{Analisis Ketersediaan Air Tanah}

Analisis ketersediaan air tanah diperoleh dengan perhitungan cadangan air tanah, mengacu standardisasi nasional Indonesia (SNI) nomor 137121-2005, tentang penyelidikan potensi air tanah skala 1:100.000 atau lebih besar (BSN, 2005). Perhitungan cadangan air bawah tanah menggunakan data tebal akuifer (diperoleh dari hasil interpretasi geolistrik atau data resitivitas), sebaran akuifer baik tertekan maupun tidak tertekan. Untuk mendapatkan nilai luas air tanah, data resistivitas hasil pengukuran dianalisis dengan cara linterpolasi litoblending. Interpolasi tersebut adalah menghubungkan data atau nilai yang sama antar titik perlapisan log resistivitas dari setiap pengukuran berdasarkan kesamaan batuan (litologi) (Singhal and Gupta, 2010). Nilai besar ketersediaan air tanah (volume air tanah) diperoleh dari pendekatan data volume batuan dengan sifat pembawa air tanah (yang didominasi pada perlapisan batuan batulempung tufan, batugamping tufan) yang diperoleh secara keruangan dengan bantuan aplikasi sistem informasi geografi (SIG), kemudian dikonversi dengan pendekatan kemampuan air yang tersimpan dari nilai porositas efektif atau specific yield (Sy). Ketersediaan air tanah, diperoleh dari rumus pendekatan, sebagai berikut:

$\begin{aligned} \text { Volume air }= & \text { volume batuan pembawa air tanah } \mathrm{x} \\ & \text { nilai Specific yield (Sy) }\end{aligned}$

dimana:

volume batuan : volume (luas x tebal akuifer) hasil intrepretasi geolistrik

Specific yield (Sy) : porositas efektif (Tabel 2)

Nilai Specific yield (Sy) atau porositas efektif, merupakan perbandingan dalam persen (\%) air yang dapat diambil dari tanah atau batuan yang jenuh air dibandingkan dengan volume total batuan atau tanah (Todd and Mays, 2005). Nilai Specific yield (Sy) disajikan pada Tabel 2 .

Tabel 2. Nilai Specific Yield (Sy) Pada Setiap Batuan 


\begin{tabular}{ccl}
\hline \hline $\begin{array}{c}\text { Porositas } \\
\text { batuan (\%) }\end{array}$ & $\begin{array}{c}\text { Specific yield (Sy)/ } \\
\text { porositas efektif }(\%)\end{array}$ & \multicolumn{1}{c}{ Batuan (LitologI) } \\
\hline $45-55$ & $1-8$ & Lanau \\
$50-60$ & $3-10$ & Lempung \\
$40-50$ & $23-38$ & $\begin{array}{l}\text { Campuran kerikil kasar } \\
\text { dan menengah }\end{array}$ \\
$35-40$ & $23-27$ & Pasir seragam \\
$30-40$ & $24-26$ & Campuran pasir halus \\
$30-35$ & $23-25$ & dan menengah \\
$30-40$ & $21-23$ & Kerikil \\
$20-35$ & $21-27$ & Kerikil dan pasir \\
$10-20$ & $5-10$ & Batupasir \\
$1-10$ & 38 & Berpih \\
\hline
\end{tabular}

\subsection{Analisis Kebutuhan Air Persemaian}

Analisis kebutuhan air persemaian dengan jumlah satu (1) juta bibit pertahun, mengacu Peraturan Menteri Lingkungan Hidup dan Kehutanan (Permen LHK), tentang penyelenggaraan perbenihan tanaman hutan nomor P.3 / MENLHK / SETJEN/ KUM.1 /1/2020 dan mengacu Peraturan Direktur Jenderal Pengendalian Daerah Aliran Sungai Dan Hutan Lindung (Perdirjen PDASHL) nomor P.5/PDASHL /SET /KUM.1/4/2019, tentang petunjuk pelaksanaan pembangunan dan pengelolaan persemaian permanen (Permen LHK, 2020).

\subsection{Neraca Ketersediaan Air Tanah Terhadap Kebutuhan Air Persemaian}

Analisis neraca ketersediaan air terhadap kebutuhan diperoleh dari selisih nilai tersebut, yaitu nilai ketersediaan air tanah dikurangi nilai kebutuhan air persemaian dalam satu tahun, mengacu standardisasi nasional Indonesia (SNI) nomor 137121-2005, tentang penyelidikan potensi air tanah skala 1:100.000 atau lebih besar (BSN, 2005).

\section{Hasil dan Pembahasan}

\subsection{Analisis Ketersediaan Air Tanah dari Data Resistivitas (Geolistrik)}

Ketersediaan air tanah diperoleh dari interpretasi hasil pengukuran geolistrik di bawah permukaan bumi. Pengukuran geolistrik sebanyak empat (4) titik. Lokasi pengukuran titik geolistrik disajikan pada Gambar 5. Penentuan lokasi titik geolistrik didasarkan atas keterdapatan ruang terbuka (purposive sampling). Hasil dari pengukuran geolistrik, diperoleh nilai resistivitas atau nilai tanahan jenis (ohm $\mathrm{m}$ ) dari setiap perlapisan didalam tanah. Dari data resistivitas diolah dengan pendekatan maching curve untuk mendapatkan kondisi permukaan berupa nilai log resistivitas, kemudian dianalisis dengan kondisi dilapanagn. Distribusi sebaran nilai resistivitas disajikan pada Gambar 6. Rentang nilai resistivitas hasil pengukuran berkisar 1,97 - 262,56 ohm m. Distribusi nilai resistivitas bagian utara (LB01 dan LB03) menunjukkan rentang nilai yang dominan tinggi hingga 262,56 ohm, sedangkan bagian selatan (LB02 dan LB04) didominasi nilai $\pm 54 \mathrm{ohm} \mathrm{m}$. Nilai resistivitas \pm 54 ohm $\mathrm{m}$ pada bagian selatan dipengaruhi oleh formasi batuan yang kompak dengan padatan. Distribusi nilai dengan nilai $54 \mathrm{ohm}$ terdisistribusi hingga bagian permukaan yang mengakibatkan terjadi singkapan batuan padat berupa batugamping kompak

Berdasarkan hasil pengolahan hasil geolistrik diperoleh lima (5) kelompak satuan batuan. Kelompok satuan batuan tersebut antara lain: (1) tanah penutup atas (soil), (2) satuan batulempung tufan, (3) satuan batulanau tufan, (4) satuan batulanau tufan, dan (5) satuan batugamping. Satuan kelompok tanah penutup atas merupakan material tanah dari hasil pelapukan batugamping yang berukuran $<10$ mikron atau berukuran lempung dan lanau. Satuan tanah penutup (soil) memiliki nilai resistivitas 8,33 - 28, 68 ohm $\mathrm{m}$ (Gambar 6). Pada satuan kelompok tanah penutup atas (soil), terdapat beberapa kenampakan parafragmen hingga bongkah batugamping yang berada disekitar kedalaman tanah penutup atas (soil). Kenampakan tersebut (bongkah batugamping) mengindikasikan terjadinya proses proses pelapukan dari batugamping secara setempat (lokal) (Febriarta dkk, 2020; Singhal and Gupta, 2010). Satuan tanah penutup atas (soil) terdapat hingga kedalaman 0,7 - 1,65 m dibawah permukaan tanah.

Kelompok satuan batulempung tufan secara umum terdapat pada Formasi Batugamping Berlapis (Ratman dan Yasin,1978). Berdasarkan pengukuran dan analisis, satuan nilai tersebut diketahui pada nilai rentang 1,96-12,10 ohm m. Nilai resistivitas pada satuan ini relatif kecil dikarenakan listrik potensial yang terhantar kedalam bumi melewati material yang tidak keras atau padatan. Berdasarkan interpretasi data tanahan jenis (resistivitas) keterdapatan satan batulempung tufan berada pada kedalaman 40,92-70 $\mathrm{m}$ (ketebalan 27,97 m). Identifikasi tuffan dipengaruhi oleh aktifitas vulkanik pada masa pembentukannya. Satuan batulanau tufan pada masa pembentukannya seperti pada satuan batulempung tufan yang dipengaruhi oleh aktivitas vulkanik (ESDM, 1995a; Ratman dan Yasin, 1978).

Satuan batulanau tufan memiliki nilai resistivitas yang rendah yaitu $\pm 10,61 \mathrm{ohm} \mathrm{m}$ seperti hasil interpretasi pada titik LB02 (Gambar 6). Satuan batulanau berada pada kedalaman 1,41- 2,29 m dibawah permukaan tanah. Nilai resistivitas yang relatif kecil tersebut menunjukkan bahwa pada satuan batulanau tufan memiliki sifat batuan yang tidak kompak atau relatif rendah (Febriarta dan Larasati, 2020; Telford et al, 2004).

Satuan batugamping, merupakan hasil interpretasi yang paling dominan dari pengukuran geolistrik. Satuan batugamping memiliki nilai resistivitas 28,48 - 72,97 ohm $\mathrm{m}$. Nilai resistivitas pada batugamping yang relatif kecil tersebut mengindikasikan keterdapatan air pada lapisannya tersebut (Todd and Mays, 2005). Satuan batugamping konglomerat, merupakan perlapisan batuan yang berada pada bagian bawah dari Formasi Batugamping Berlapis (Tml), dengan kedalaman 98,63-140 m (ketebalan 41,37) dibawah permukaan tanah Satuan batuan batugamping berlapis memiliki nilai 
resistivitas 125,35-262,56 ohm m, seperti pada hasil pengukuran titik LB01 (Gambar 6).

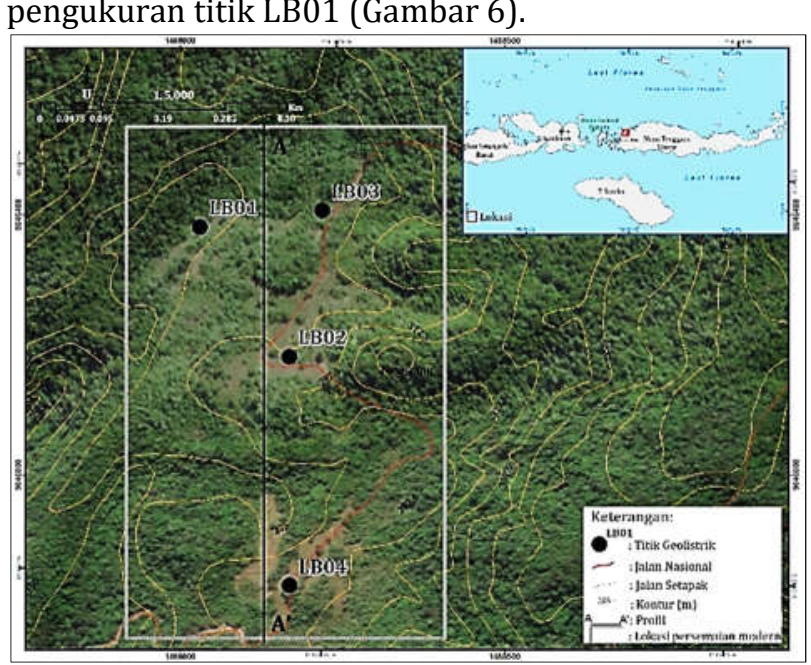

Gambar 5. Pengukuran dengan Konfigurasi Schlumberger dengan Rentangan $500 \mathrm{~m}$

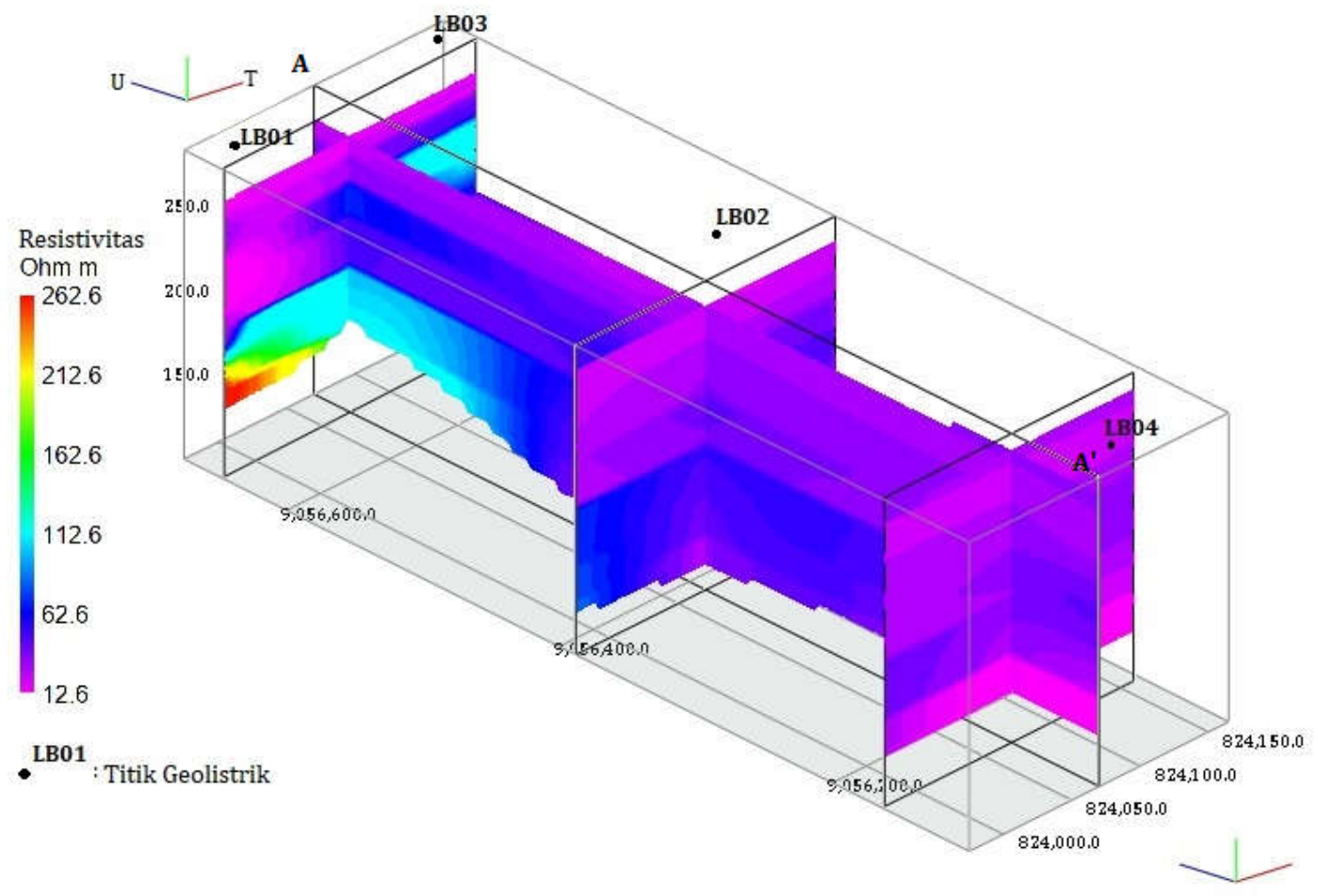

Gambar 6. Distribusi Nilai Resistivitas (Tahanan Jenis) (ohm m)

Nilai korelasi nilai resitivitas terhadap keterdapatan air tanah menurut Uhlemann et al (2017) berkisar antara 0-500 ohm m. Berdasarkan interpretasi keterdapatan air tanah pada formasi batugamping berlapis, berada pada rentang nilai rsistivitas 0-120 ohm $\mathrm{m}$. Titik LB01 terletak di koordinat 50S $823975 \mathrm{mE}$ dan $9056645 \mathrm{mN}$ dengan elevasi $279 \mathrm{mdpl}$. Pada titik ini dilakukan pengukuran geolistrik dengan bentangan total $500 \mathrm{~m}$ yang menghasilkan analisis dengan kedalaman total $140 \mathrm{~m}$. Dari hasil analisis didapatkan tujuh (7) litologi batuan dari atas ke bawah yang terdiri dari tanah penutup atas (soil) dengan ketebalan 0,7 m, litologi batulempung tufan dengan ketebalan $0,77 \mathrm{~m}$, litologi batulanau tufan dengan ketebalan 5,16 m, litologi batugamping dengan ketebalan 34,95 m, litologi batulempung tufan dengan ketebalan 29,08 m, litologi batugamping dengan ketebalan $27,97 \mathrm{~m}$, dan yang paling bawah terdapat litologi batugamping konglomeratan dengan ketebalan terukur 41,37 m. Berdasarkan keterdapatan batuan dengan sifat pembawa air tanah, diketahui pada lapisan batuan batulempung tuffan dan batulanau tufan 6,63 - 41,58 $m$ dan batugamping 70,66 - 98,63 m (Gambar 7).

Titik LB02 terletak di koordinat 50S $824114 \mathrm{mE}$ dan $9056450 \mathrm{mN}$ dengan elevasi $292 \mathrm{mdpl}$. Pada titik ini dilakukan pengukuran geolistrik dengan bentangan total $500 \mathrm{~m}$ yang menghasilkan analisis dengan kedalaman total $180 \mathrm{~m}$. Dari hasil analisis didapatkan lima (5) litologi batuan dari atas ke bawah yang terdiri dari tanah penutup atas (soil) dengan ketebalan 1,41 $\mathrm{m}$, litologi batugamping dengan ketebalan 2,5 m, litologi batulempung tufan dengan ketebalan 2,29 m, litologi batugamping dengan ketebalan 113,8 mdan yang paling bawah terdapat litologi batulempung tufan dengan ketebalan terukur $60 \mathrm{~m}$. Berdasarkan 
keterdapatan batuan dengan sifat pembawa air tanah, diketahui pada lapisan batuan batugamping perselingan batulempung tufan 6,20 - $120 \mathrm{~m}$.

Titik LB03 terletak di koordinat 50S $824161 \mathrm{mE}$ dan $9056673 \mathrm{mN}$ dengan elevasi 319 mdpl. Pada titik ini dilakukan pengukuran geolistrik dengan bentangan total $500 \mathrm{~m}$ yang menghasilkan analisis dengan kedalaman total $100 \mathrm{~m}$. Dari hasil analisis didapatkan delapan (8) litologi batuan dari atas ke bawah yang terdiri dari tanah penutup atas (soil) dengan ketebalan $0,97 \mathrm{~m}$, litologi batugamping konglomeratan dengan ketebalan 1,693 m, litologi batulempung tufan dengan ketebalan 1,26 m, litologi batugamping dengan ketebalan $11,53 \mathrm{~m}$, litologi batulempung tufan dengan ketebalan $11,69 \mathrm{~m}$, litologi batugamping dengan ketebalan $17,2 \mathrm{~m}$, litologi batugamping konglomeratan dengan ketebalan 26,04 $m$ dan yang paling bawah terdapat litologi batulempung tufan dengan ketebalan terukur 29,617 m. Berdasarkan keterdapatan batuan dengan sifat pembawa air tanah, diketahui pada lapisan batugamping konglomerat 3,92 - 15,45 dan batulempung tufan 27,14 - 44,34 m.

Titik LB04 terletak di koordinat 50S $824120 \mathrm{mE}$ dan $9056102 \mathrm{mN}$ dengan elevasi 299 mdpl. Pada titik ini dilakukan pengukuran geolistrik dengan bentangan total $500 \mathrm{~m}$, yang menghasilkan analisis dengan kedalaman total $160 \mathrm{~m}$. Dari hasil analisis didapatkan enam (6) litologi batuan dari atas ke bawah yang terdiri dari tanah penutup atas (soil) dengan ketebalan 1,65 m, litologi batulempung tufan dengan ketebalan 5,85 m, litologi batugamping dengan ketebalan 16,54 m, litologi batulempung tufan dengan ketebalan 22,2 m, litologi batugamping dengan ketebalan 60,44 $\mathrm{m}$ dan yang paling bawah terdapat litologi batulempung tufan dengan ketebalan terukur 53,32 m. Berdasarkan keterdapatan batuan dengan sifat pembawa air tanah, disajikan pada Tabel 3.

Tabel 3. Keterdapatan Air Tanah pada Perlapisan Batuan (Litologi)

\begin{tabular}{|c|c|c|c|c|c|c|c|}
\hline \multirow[t]{2}{*}{ Kode } & \multicolumn{3}{|c|}{ Koordinat UTM (Zona $50 \mathrm{~S}$ ) } & \multirow{2}{*}{$\begin{array}{l}\text { Resistivitas } \\
\text { (ohm m) }\end{array}$} & \multirow[t]{2}{*}{ Fomasi Batuan (litologi) Akuifer } & \multirow{2}{*}{$\begin{array}{l}\text { Kedalaman Akuifer } \\
\text { (m) }\end{array}$} & \multirow{2}{*}{$\begin{array}{c}\text { Tebal Akuifer } \\
(\mathrm{m})\end{array}$} \\
\hline & $\mathrm{x}$ & $\mathrm{y}$ & $\mathrm{z}$ & & & & \\
\hline \multirow[t]{2}{*}{ LB01 } & 823975 & 9056645 & 279 & 4,64 & Batulempung tuffan dan batulanau tufan & $6,63-41,58$ & 34,95 \\
\hline & & & & 27,97 & Batugamping & $70,66-98,63$ & 27,97 \\
\hline LB02 & 824114 & 9056450 & 292 & 51,30 & Batugamping perselingan batulempung tufan & $6,20-120$ & 113,8 \\
\hline \multirow[t]{2}{*}{ LB03 } & 824161 & 9056673 & 319 & 166,35 & Batugamping konglomerat & $3,92-15,45$ & 11,53 \\
\hline & & & & 11,69 & Batulempung tufan & $27,14-44,34$ & 17,20 \\
\hline \multirow[t]{2}{*}{ LB04 } & 824120 & 9056102 & 299 & 36,06 & Batugamping tufan & $7,5-24,04$ & 16,54 \\
\hline & & & & 54,49 & Batugamping tufan & $46,24-106,68$ & 60,24 \\
\hline
\end{tabular}

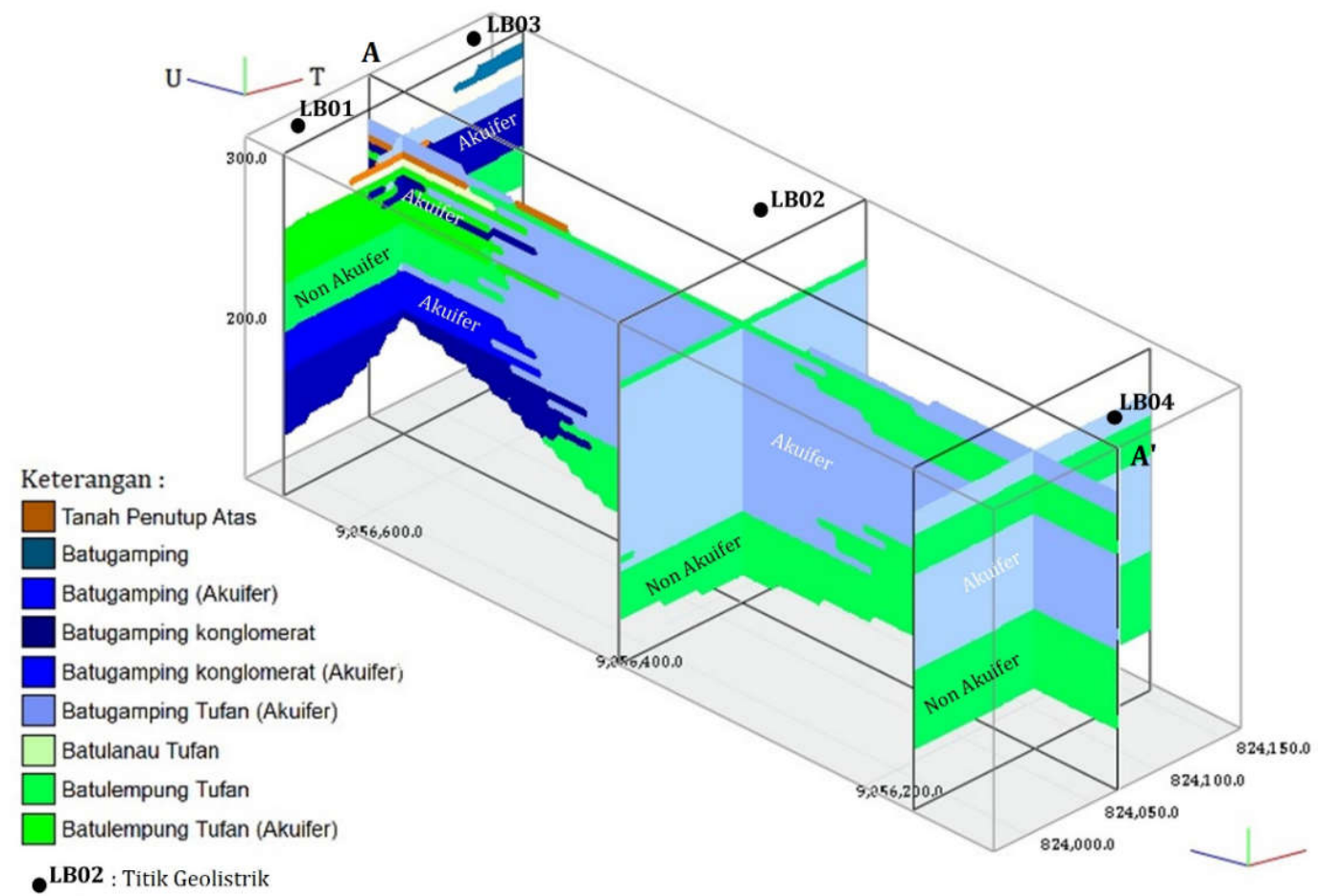

Gambar 7. Sebaran Air Tanah (Akuifer)

Ketersediaan air tanah di lokasi persemaian, diketahui dengan kemampuan batuan menyimpan air tanah dari potesi posositas efektifnya (\%) ((Todd and Mays, 2005; Febriarta dkk, 2019). Setiap pelapisan batuan yang memiliki sifat pembawa air tanah (Tabel 3) dikonversi dengan nilai porositas efektif (\%) pada batuan. Lapisan pembawa batuan pembawa sifat air tanah tersebut antara lain: batugamping, batugamping konglomerat, batulempung tufan, batugamping tufan. Volume dari perlapisan batuan tersebut dihitung dalam satuan $\mathrm{m}^{3}$. Berdasarkan hasil perhitungan, diketahui bahwa lapisan air tanah atau akuifer didominasi pada lapisan batugamping, dengan sifat aliran beripa celah, rekah, saluran dan pelarutan 
sehingga nilai porositas efektif (\%) berkisar 25-38\% (Tabel 4). Sehingga diketahui bahwa cadangan air tanah di sekitar lokasi persemaian modern adalah $69.944,31 \mathrm{~m}^{3}$.

Tabel 4. Ketersediaan Air Tanah pada Setiap Perlapisan Batuan

\begin{tabular}{lrrr}
\hline \multicolumn{1}{c}{ Formasi Batuan (Litolog) } & Volume batuan $\left(\mathrm{m}^{3}\right)$ & Porositas Efektif (\%) / Specific yield (Sy) & Ketersediaan Air Tanah $\left(\mathrm{m}^{3}\right)$ \\
\hline Batugamping & $12.739,041$ & 38 & $4.840,83$ \\
Batugamping konglomerat & 130,965 & 28 & 36,67 \\
Batulempung tufan & $13.684,116$ & 25 & $3.421,02$ \\
Batugamping tufan & $246.583,100$ & 25 & $61.645,77$ \\
& & & $69.944,31$ \\
\hline
\end{tabular}

\subsection{Neraca Ketersediaan Air Tanah Terhadap Kebutuhan Air Persemaian}

Kebutuhan air yang diperlukan dalam penyiapan media, yaitu pencampuran media tanam ke polybag rata-rata secara umum untuk tanaman hutan adalah 1 $\mathrm{mm} /$ hari/bibit atau $0,000001 \mathrm{~m}^{3} /$ hari/bibit. Kebutuhan air untuk penaburan dan penyapihan tanaman hutan rata-rata secara umum adalah 4,65 liter/hari/bibit atau $0,00000465 \mathrm{~m}^{3} /$ hari/bibit, masa persemaian pemeliharaan perhari rata-rata tanaman hutan adalah $6,32 \mathrm{~mm} /$ hari atau 0,00000632 $\mathrm{m}^{3} /$ hari/bibit. Kebutuhan personel persemaian sejumlah sembilan (9) orang dengan estimasi kebutuhan air 60 liter/hari/orang atau 0,06 $\mathrm{m}^{3} /$ hari/orang (BSN, 2005).
Estimasi persemaian bibit adalah satu (1) juta bibit per tahun atau dengan sekema dalam satu tahun terdapat dua (2) kali penaburan (2 rotasi) yang terdiri atas penaburan, penyapihan, pengisian kantong bibit (polybag). Waktu yang diperlukan satu (1) kali rotasi penaburan (penaburan, penyapihan, pengisian polybag) membutuhkan watu 5 bulan (Perdirjen PDASHL, 2019). Sekema perencanaan persemaian dua (2) kali rotasi, siap menjadi bibit untuk ditanam pada bulan ke-5 dan bulan ke-10, kemudian estimsi waktu untuk distribusi bibit tanaman hutan. Kebutuhan air persemaian dalam satu (1) tahun dengan produksi 1 juta bibit disajikan pada Tabel 5.

Tabel 5. Kebutuhan Air Persemaian dalam Satu (1) Tahun

\begin{tabular}{|c|c|c|c|}
\hline Jenis Pemakaian Air & Kebutuhan $\left(\mathrm{m}^{3} /\right.$ hari) & Durasi & Total $\left(\mathrm{m}^{3} /\right.$ tahun $)$ \\
\hline Penyiapan media (polybag) & 0,00000100 & 60 hari ( 2 bulan) & 60,00 \\
\hline Penaburan (rumah kecambah) & 0,00000465 & 60 hari ( 2 bulan) & 279,00 \\
\hline Penyapihan (rumah kecambah, area naungan) & 0,00000465 & 60 hari ( 2 bulan) & 279,00 \\
\hline Pemeliharaan Bibit (area terbuka, rumah bahan) & 0,00000632 & 120 hari ( 4 bulan) & 758,40 \\
\hline Personel Persemaian (9 Orang) & 0,06 & 365 hari (1 tahun) & 365,06 \\
\hline Operasioanl persemaian & 0,50 & 365 hari ( 1 tahun) & 182,50 \\
\hline & & Total Kebutuhan & $1.923,96$ \\
\hline
\end{tabular}

Evaluasi air tanah untuk persemaian modern di diperoleh dari selisih dari nilai ketersediaan air tanah (Tabel 4) dikurangi dengan selisih nilai kebutuhan air persemaian tanaman hutan satu (1) juta bibit pertahun (Tabel 5). Berdasarkan hasil perhitungan, diketahui bahwa hasil neraca air bernilai surplus atau dapat menuhi kebutuhan air untuk persemaian dalam satu (1) tahun dengan dua (2) kali rotasi persemaian. Nilai neraca evaluasi kebutuhan air persemaian disajikan pada Tabel 6 .

Tabel 6. Neraca Kebutuhan Air Persemaian dalam 1 Tahun (2 kali rotasi persemaian)

\begin{tabular}{cccc}
\hline \hline $\begin{array}{c}\text { Ketersediaan Air } \\
\text { Tanah } \\
\left(\mathrm{m}^{3}\right)\end{array}$ & $\begin{array}{c}\text { Kebutuhan Air } \\
\text { Persemaian } \\
\left(\mathrm{m}^{3} / \text { tahun }\right)\end{array}$ & Neraca Air & Keterangan \\
$\left(\mathrm{m}^{3} /\right.$ tahun $)$ & Surplus \\
\hline $69.944,31$ & $1.923,96$ & $68.020,35$ & \\
\hline
\end{tabular}

Kebutuhan air persemaian modern satu (1) juta bibit tanaman hutan dengan masa rotasi dua (2) kali pembibitan dalam setahun adalah 1.923,96 $\mathrm{m} 3 /$ tahun, nilai pemakaian tersebut sebesar 2,75\% dari ketersediaan air tanah. Berdasarkan ketersediaan total air tanah sebesar 69.944,31 m3, masih terdapat $97,25 \%$ belum termanfaatkan disekitar lokasi peremaian ( $\pm 30 \mathrm{ha}$ ).

Lokasi persemaian modern merupakan wilayah hutan dari kawasan bentang alam karst (KBAK)
Nggorang Mangarai Barat yang sangat strategis untuk dikembangan menjadi kegiatan wisata. Dalam rangka mengembangkan daerah wisata prioritas di Labuan Bajo, lokasi persemaian modern dapat dikembangkan menjadi tempat eduwisata persemaian modern dan peternakan kambing. Menurut BSN (2002) kebutuhan air untuk kegiatan pariwisata adalah $90 \mathrm{l} /$ hari. Nilai penggunaan air sebesar $90 \mathrm{l} / \mathrm{hari}$ merupakan akumulasi rata-rata dengan jumlah pengunjung 30 orang dari penggunaan air toilet, pemeliharaan dan operasinal kebersihan (BSN, 2002; DPU Cipta Karya, 1996; Setyaningrum dan Febriarta, 2019). Sehingga jika diestimasi penggunaan air untuk kegiatan wisata dalam satu tahun sebesar $32,83 \mathrm{~m}^{3} /$ tahun atau sebesar $0,05 \%$ dari ketersediaan air. Sedangkan untuk kebutuhan air peternakan berupa kambing adalah 5 l/ekor/hari (BSN, 2002; Tamelan dan Harijono, 2019). Jika pengembangan peternakan kambing dengan jumlah 30 ekor, maka kebutuhan air untuk peternakan kambing adalah $54,75 \mathrm{~m}^{3}$ /tahun atau sebesar $0,07 \%$ dari nilai ketersediaan air tanah. Dengan proyeksi pengembangan menjadi tempat wisata persemaian modern dan peternakan kambing, ketersediaan air tanah masih bernilai surplus, seperti hasil neraca perbandingan yang disajikan pada Tabel 7. 
Tabel 7. Neraca Air dengan Pengembangan Wisata

\begin{tabular}{lr}
\hline \hline Jenis Pemanfaatan & Volume $\left(\mathrm{m}^{3} / \mathrm{tahun}\right)$ \\
\hline Ketersediaan Air & $69.944,31$ \\
Persemaian bibit modern & $1.923,96$ \\
Wisata (Eduwisata persemaian modern) & 32,85 \\
Peternakan Kambing (30 ekor) & 54,75 \\
Cadangan (Surplus) & $67.932,75$ \\
\hline
\end{tabular}

Berdasarkan hasil perhitungan diketahui neraca air dari pemanfaatan persemaian bibit modern, eduwisata persemaian modern dan pengembangan peternakan berupa kambing masih terdapat cadangan sebesar 67.932,75 $\mathrm{m}^{3}$ /tahun atau sebesar 97,12\% dari ketersediaan air tanah. Nilai neraca ketersediaan air tanah tersebut sangat cukup untuk kegiatan wisata di persemaian pembibitan Nggorang Manggarai Barat, Labuan Bajo,

\section{Kesimpulan dan Saran}

Ketersediaan air tanah untuk kebutuhan persemaian modern sangat cukup (suplus) dengan estimasi pemakaian sebesar $2,75 \%$ dari nilai cadangan air tanah dalam satu tahun. Penggunaan air total dengan pengambangan wisata sebesar 2,87\%, dengan nilai cadangan (surplus) sebesar 67.932,75 $\mathrm{m}^{3} /$ tahun atau $97,12 \%$ dari ketersediaan air tanah.

Secara umum keterdapatan air tanah berada pada formasi satuan batugamping. Untuk mendapatkan kuantitas air tanah yang maksimal, pengambilan air tanah (pengeboan) mengambil air tanah dalam ( $>50$ $\mathrm{m}$ ), seperti pada Titik LB01 pada lapisan batugamping dengan kedalaman 70,66 - 98,63 m dengan potensi ketebalan akuifer 27,97 m. Pada titik LB02 kedalaman yang potensial berada pada lapisan batugamping perselingan batulempung tufan dengan kedalaman 6,20 - $120 \mathrm{~m}$, dan potensi ketebalan akuifer 113,8 m. Pengambilan air tanah pada titik LB03, memiliki keterusan yang potenisal berada pada lapisan batulempung tufan dengan kedalam 27,14 - 44,34 m dengan potensi ketebalan akuifer $17,20 \mathrm{~m}$. Potensi dengan paling baik pengambilan air tanah berada pada titik LB04 pada perlapisan batugamping tufan degan kedalaman 46,24 - 106,68 m dan potensi ketebalan 60,24 m. Titik LB04 memiliki potensi debit relatif paling tinggi dibanding ketiga pengukuran yang lain, hal tersebut dipengaruhi oleh kondisi pori atau rongga antar butir didominasi oleh material pasiran dan tuff yang mudah melolosakan air tanah. Saran untuk mendapatakn kualitas air tanah yang sesuai untuk persemaian perlu dilakukan uji kualitas air sesuai dengan standar baku mutu peruntukan persemaian bibit tanaman.

\section{Ucapan Terima Kasih}

Artikel ini merupakan analisis lanjut dari kegiatan Perencanaan Pembangunan Persemaian Modern Labuan Bajo Provinsi Nusa Tenggara Timur yang difasilitasi oleh Kementerian Lingkungan Hidup dan Kehutanan (KLHK) Republik Indonesia. Ucapan terimakasih ditujukan kepada Kementerian Lingkungan Hidup dan Kehutanan (KLHK) Republik 580
Indonesia dan Kesatuan Pengelolaan Hutan (KPH) Labuan Bajo Wilayah Manggarai Barat (Mabar) yang bersedia memberikan bantuan pelaksanaan penelitian ini.

\section{DAFTAR PUSTAKA}

Abrishambaf, O., Faria, P., Gomes, L., Vale, Z. 2020. Agricultural Irrigation Scheduling for A Crop Management Systemconsidering Water and Energy Use Optimization. Energy Report. Vol. 6. Pages 133139.

Badan Standardisasi Nasional (BSN). 2002. Standar Nasional Indonesia 19-67128.1-2002 tentang Penyusunan Neraca Sumber daya-Bagian 1: Sumber Daya Air Spasial. Badan Standardisasi Nasional (BSN). Jakarta.

Badan Standardisasi Nasional (BSN). 2005. Standar Nasional Indonesia 13-7121-2005 Penyelidikan Potensi Air Tanah Skala 1:100.000 atau Lebih Besar. Badan Standardisasi Nasional. Jakarta.

Badan Standardisasi Nasional (BSN). 2012. Standar Nasional Indonesia 2818:2012 Tata Cara Pengukuran Geolistrik Schlumberger untuk Eksplorasi Air Tanah. Badan Standardisasi Nasional. Jakarta.

Balasubramanya, S., Stifel, D. 2020. Viewpoint: Water, Agriculture \& Poverty in an Era of Climate Change: Why Do We Know So Little?. Food. Policy. Vol. 93. Pages 1-10.

Energi dan Sumber Daya Mineral (ESDM). 1995a. Litologi Akuifer Bali Nusra. Energi dan Sumber Daya Mineral (ESDM). Jakarta.

Energi dan Sumber Daya Mineral (ESDM). 1995b. Produktivitas Akuifer Bali Nusra. Energi dan Sumber Daya Mineral (ESDM). Jakarta.

Energi dan Sumber Daya Mineral (ESDM). 2018. Cekungan Air Tanah (CAT) Bali Nusra. Energi dan Sumber Daya Mineral (ESDM). Jakarta.

Dirjen Pekerjaan Umum Cipta Karya (DPU Cipta Karya). 1996. Pengembangan Kawasan Perkotaan, Kawasan Perdesaan. Dirjen Pekerjaan Umum. Jakarta.

Febriarta, E., Prabawa, B.A., dan Rosaji, F.S.C. 2018. Sumber Daya Air Pelapis, Kepulauan Karimata, Kabupaten Kayong Utara. Prosiding Seminar Nasioanl Ke-4: Pengelolaan Pesisir dan Daerah Aliran Sungai. Vol. 4. Hal 181-186.

Febriarta, E., Suswanti, dan Novandaru, S. 2019. Interpretasi Electrical Resistivity Tomography (ERT) Untuk Pendugaan Air Tanah Dangkal Pada Formasi Gunungapi Muda. Jurnal nasinal Teknologi Terapan. Vol. 13 No. 1. Hal 49-62.

Febriarta, E., dan Larasati, A. 2020. Karakteristik Akuifer Air Tanah Dangkal di Endapan Muda Merapi Yogyakarta. Jurnal Sains dan Teknologi Lingkungan. Vol. 12 No. 2. Hal 84-99.

Febriarta, E., Oktama, R., dan Purnama, S. 2020. Analisis Daya Dukung Lingkungan Berbasis Jasa Ekosistem Penyedia Pangan dan Air Bersih di Kabupaten Semarang. Geomedia. Vol. 18 No. 1. Hal 12-24.

Febriarta, E., dan Oktama, R. 2020. Pemetaan Daya Dukung Lingkungan Berbasis jasa ekosistem Penyedia Pangan dan Air Bersih di Kota Pekalongan. Jurnal Ilmu Lingkungan. Vol. 18 No. 2. Hal 283-289.

Febriarta, E., dan Purnama, S. 2020. Identifikasi Keterdapatan Air Tanah Dengan Electromagnetic Very Low Frequency (EM-VLF) di Non Cekungan Air Tanah Kecamatan Ungaran Timur. Jurnal Geosains dan Teknologi. Vol. 3 No. 2. Hal 52-62. 
Febriarta, E., S., Marfai, M. A, Hizbaron, D. R., dan Larasati A. 2020. Kajian Spasial Multi Kriteria DRASTIC Kerentanan Air tanah Pesisir Akuifer Batugamping di Tanjungbumi Madura. Jurnal Ilmu Lingkungan. Vol. 18 No. 3. Hal 476-487.

Fetter, C. W. 2004. Applied Hydrogeology (5th ed.). Ogio. Merril Publishing Company.

Hadi, D.W. 2020. Pembangunan Persemaian Modern Mendukung Wisata Labuan Bajo. Kementerian Lingkungan Hidup dan Kehutanan. Jakarta.

Kurniaty, R., Danu. 2012. Teknik Persemaian. Balai Penelitian Teknologi Perbrnihan Tanaman Hutan. Bogor.

Lowrie, and William. 2007. Fundamental of Geophysics (2nd ed.). New York. Cambridge University Press.

Maino, P.A., Manu, E., Yidana, S.M., Agyekum, W.A., Stiger, T., Duah, A.A., Preko, K. 2019. Application of 2D-Electrical resistivity tomography in delineating groundwater potential zones: Case study from the voltaian super group of Ghana. Journal Of African Earth Sciences. Vol. 160. Pages 1-12.

Milsom. 2003. Field Geophysics, The Geological Field Guide Series (3rd ed.). London. West Sussex: John Wiley \& Sons.

Pramono, A.A., Hudrajat, D.J., Nurhasbi, Danu. 2016. PrinsipPrinsip Cerdas Pembibitan Tanaman Hutan.Penerbit Swadaya. Jakarta.

Peraturan Menteri Energi dan Sumber Daya Mineral (Permen ESDM). 2012. Penetapan Kawasan Bentang Alam Karst Nomor 17 Tahun 2012. Republik Indonesia. Jakarta.

Peraturan Menteri Energi dan Sumber Daya Mineral (Permen ESDM). 2017. Cekungan Air Tanah di Indonesia Nomor 2 Tahun 2017. Republik Indonesia. Jakarta.

Peraturan Direktur Jenderal Pengendalian Daerah Aliran Sungai Dan Hutan Lindung (Perdirjen PDASHL). Petunjuk Pelaksanaan Pembangunan Dan Pengelolaan Persemaian Permanen 2019 Nomor :P.5/PDASHL/SET/KUM.1/4/2019. Republik Indonesia. Jakarta.

Peraturan Menteri Lingkungan Hidup dan Kehutanan (Permen LHK). 2020. Penyelenggaraan Perbenihan Tanaman
P.3/MENLHK/SETJEN/KUM.1/1/2020. Republik Indonesia. Jakarta.

Ratman, N., dan Yasin, A. 1978. Peta Geologi Lembar Komodo, Nusa Tenggra. Direktorat Geologi. Bandung.

Setyaningrum, A., dan Febriarta, E. 2019. Analisis Kesesuaian dan Daya Dukung Ekowisata Pantai Kategori Rekreasi Pantai Kuwaru Kabupaten Bantul Yogyakarta. Prosiding Seminar Nasional Pengelolaan Pesisir dan Daerah Aliran Sungai ke-5. Vol. 5. Hal 3641.

Singhal, B. B. S., \& Gupta, R. P. 2010. Applied Hydogeology of Fracture Rock. London. Springer Dordrecht Heidelberg London.

Tamelan, P.G., dan Harijono. 2019. Pemenuhan Kebutuhan Air Minum Penduduk, Ternak dan Pertanian Didaerah Pedesaan Lahan Keringberiklim Kering Pulau Rote. Jurnal Ilmuah Teknologi FST Undana. Vol. 13 No. 1. Hal 39-47.

Telford, W. M., Geldart, L. P., and Sheriff, R. E. 2004. Applied Geophysics (2nd ed.). London. Cambridge University Press.

Todd, D. K., and Mays, L. W. 2005. Groundwater Hydrology (3rd ed.). Denver: John Wiley \& Sons, Inc.

Traitler, H., Dubois, M., Heikes, K., Petiard, V., Zilberman. 2018. Megatrends in Food and Agriculture. Jhon Wiley \& Sons. United Kingdom.

Uhlemann, S., Kuras, O., Richards, L. A., Naden, E., \& Polya, D. A. 2017. Electrical Resistivity Tomography Determines The Spatial Distribution of Clay Layer Thickness and Aquifer Vulnerability. Kandal Province. Cambodia. Journal of Asian Earth Sciences, Vol. 147. Pages 402-414.

Ungureanu, C., Priceputu, A., Bugea, A. L., \& Chirică, A. 2017. Use of Electric Resistivity Tomography (ERT) for Detecting Underground Voids on Highly Anthropized Urban Construction Sites. Procedia Engineering, Vol. 209. Pages 202-209.

Valliano, E., Ridolfi, L., Laio, F. 2020. Measuring Economic Water Scarcity in Agriculture: A Cross-Country Empirical Investigation. Environmental Science and Policy. Vol. 114. Pages 73-85.

Vienastra, S., dan Febriarta, E. 2020. Penentuan Zona Kerentanan Airtanah Metode Simple Vertical Vurnerability di Pulau Yeben. Jurnal Swarnabhumi. Vol. 5 No. 2. Hal 58-66. 